\title{
sciendo
}

\section{Recovery of the prejudice caused by an insolvent company}

\author{
Cristina COJOCARU \\ Bucharest University of Economic Studies, Bucharest, Romania \\ cristina.cojocaru@drept.ase.ro
}

\begin{abstract}
A recent decision of the Romanian High Court of Justice dated 6 March 2019 offers the possibility to analyse the recovery of the prejudice caused to a creditor by a company under court proceedings after on its insolvency. The applicable regulations (i.e. Law no. 85/2015) represent the legal framework, which aims at debt payment by the insolvent debtor to his creditors. Therefore, the procedure is collective and all the known creditors are involved. Consequently, the law regulates the means and the conditions of this procedure. The prejudice caused to a creditor by the insolvent company shall be recovered following the rules of the special law and not through the general applicable rules, i.e. the Civil Code. The article aims to identify the relevant theoretical aspects and their applicability in practice by the courts of law.
\end{abstract}

Keywords: insolvency, insolvent company, prejudice, recovery of the prejudice, Romanian insolvency law.

\section{Introduction}

A recent case of the $\mathrm{I}^{\text {st }}$ Civil Section of the High Court of Cassation and Justice [1] gives us the opportunity to make an analysis on the manner and conditions under which the recovery of the damage caused to the creditor by a company that is insolvent is regulated in Romanian law, namely the ways and means of carrying out this activity.

In that case, the State, represented by the National Agency of Fiscal Administration, sued a company asking that, in contradiction with it, the court order the defendant to pay outstanding debts to the State - corporation tax and VAT - based on the provisions of the Civil Code and those of the Tax Administration Code, even though at the time the defendant was in insolvency proceedings.

The plaintiff pointed out that the conditions of tort liability are precisely fulfilled in the present case and the damage caused occurred from a criminal trial in which the debtor legal person was convicted of the offence of tax evasion.

Following the agreement to admit criminal guilt, the criminal court has left the civil action attached to the criminal side unsolved and thus the plaintiff considers itself entitled to seek recovery of the damage caused under the provisions concerning tortious civil liability.

As such, as a matter of tort liability, it is irrelevant that the debtor at that time was in insolvency proceedings, not being a dispute of the claim entered in the debts' list in order to be incidental in this case the provisions of the insolvency law.

\section{Ways of carrying out insolvency proceedings in Romanian law}

Insolvency may be carried out in two ways, namely through a general procedure or a simplified procedure (Cărpenaru, 2012, p. 680).

The general procedure requires that the debtor be in the situation provided for in Article 3 of Law no. 85/2014, i.e. be a professional as defined by law but which does not simultaneously meet the conditions laid down for those to whom the simplified procedure applies. The persons to whom the general proceedings apply shall be subject, after the observation period, either 
successively to judicial reorganization and bankruptcy proceedings, or separately, only to judicial reorganization or only to bankruptcy.

As regards the observation period, this is the period between the date of initiation of the proceedings and the date of confirmation of the reorganization plan or the date of entering the bankruptcy, as the case may be.

The simplified procedure is the procedure applicable where the debtor fulfils the conditions laid down in Article 38 of the Law, namely: professional individuals subject to the obligation to register with the Trade Register except those practicing liberal professions; family businesses and their members; debtors who do not hold any assets in the patrimony, the acts of incorporation cannot be found, the administrator cannot be found, the registered office no longer exists or does not correspond to that of the Trade Register, the legal person has been dissolved voluntarily or judicially before the application is made, debtors who by application have declared their intention to go bankrupt, and any professional person who has not obtained the authorization required by law.

In the case of this procedure, the debtor shall enter into bankruptcy proceedings directly, either on the date of the opening of insolvency proceedings or after a period of observation of not more than 60 days necessary to establish the fulfilment of the conditions required by law.

Insolvency proceedings involve either the route of judicial reorganization or that of bankruptcy.

In the case of judicial reorganization, this procedure implies the preparation, approval and implementation of a reorganization plan which aims to restructure the debtor's business, or to liquidate assets belonging to the debtor in order to make his activity viable and to be able to pay the debts to the creditors. In this case the debtor's activity therefore continues, but under certain conditions.

In the event of bankruptcy proceedings, however, the debtor's estate is liquidated to cover the debts accumulated by him. As such, his activity ceases, with efforts directed towards covering his debts from the liquidation of existing assets.

It should be noted that both procedures are alternative ways without an order of priority between them, and the choice of one or the other is made according to the economic situation of the debtor (see Turcu, 2008; Adam, Savu, 2006).

\section{Insolvency characters}

According to the legal provisions, insolvency is a judicial procedure - it is carried out under the judicial control of the bodies invested for this purpose. It has also a personal character, it seeks to satisfy the debtors' claims, which benefit from equal treatment.

\section{Conditions for the application of insolvency proceedings}

According to the current legal regulation - Article 3 of Law no. 85/2014 - the insolvency proceedings shall apply to professionals as defined in Article 3 paragraph 2 of the Civil Code, with the exception of those practicing liberal professions and those for which special provisions are laid down in respect of their insolvency arrangements. The insolvency procedure also applies to autonomous regies but not to units in pre-university education, university or scientific research. 


\section{Insolvency proceedings shall apply to:}

\section{- Companies}

Insolvency proceedings apply to companies that are set up and operate in accordance with Companies' Law no. 31/1990. These are companies regardless of their legal form. The insolvency proceedings do not apply to their branches because they do not have legal personality (Pătulea, 2005).

Insolvency proceedings shall not apply to the company's members. A company in liquidation following dissolution may be subject only to bankruptcy proceedings.

- Cooperative companies and cooperative organizations

The cooperative companies are associative forms of private law through which cooperation is carried out and have a legal regime similar to that of companies, and those in the second category are associative forms in the field of agriculture.

- Economic interest groups

The economic interest group is a company of two or more individuals or legal persons, constituted for a specified period, for the ease or economic development of its members and which is subject to insolvency proceedings.

- Any other legal person governed by private law carrying out economic activities

In this category there can be included associations or foundations that can also carry out commercial activities, can set up commercial companies and who can carry out economic activities.

\section{As regards the simplified procedure, it may apply to:}

- professionals (individuals) under the obligation to register in the Trade Register, with the exception of those practicing liberal professions.

The individual may carry out economic activities under the law, individually and independently, as an authorized natural person, as the titular entrepreneur of an individual undertaking or as members of a familiar undertaking. It can carry out economic activities in all areas, trades and occupations or professions which the law does not expressly prohibit for free enterprise except those expressly regulated by special laws.

- family enterprises, members of the family business;

The management of these family businesses shall be carried out by the representative designated by the founding agreement. Members of such a family enterprise are traders within the meaning of the law and they are jointly and severally liable for the debts contracted and in the event of insolvency the simplified procedure applies to all members, not being able to apply the enforcement procedure (Cărpenaru, 2012, p. 690).

- debtors falling within the categories referred above to whom the general insolvency procedure applies - and in addition, fulfil one of the following conditions:

(i) they do not hold any assets in their assets, (ii) the instruments of incorporation or accounting documents cannot be found, (iii) administrator cannot be found, (iv) the registered office/professional office no longer exists or does not correspond to the address in the trade register.

In these cases, the inapplicability of the general insolvency procedure is fully explained precisely by the fact that in their case, due to the situations in which they find themselves, the judicial reorganization procedure cannot be applied to them and it is therefore necessary to proceed directly to the simplified bankruptcy procedure. 
- legal persons dissolved voluntarily, judicially or by law, prior to the application, even if the judicial liquidator has not been appointed or, although appointed, the reference to his appointment, has not been entered in the Trade Register;

- debtors who have declared their intention to go bankrupt by the claim in court;

- any person carrying out professional-specific activities who has not obtained the authorization required by law for the operation of an undertaking and is not registered in the special publicity registers; the application of this Law to such persons shall not exclude the penalties applicable to the lack of authorization or registration of that person.

In that case, the plaintiff also claimed that, in the file of insolvency proceedings, the budgetary creditor did not request liability of the guilty persons, so that a double situation of compensation for the damage is created and the possibility of tortious civil liability is not removed by the existence of insolvency proceedings, the creditor being free to choose the procedure to be followed, in accordance with the principle of availability.

As such, in the plaintiff's view, the effort of obtaining the right of claim through insolvency proceedings does not preclude the possibility of attracting tortious civil liability to those guilty of causing injury, even more since the creditor did not satisfy his claim in insolvency proceedings, even though the damage existed and was known at the time of the insolvency, the creditor being registered at the debts' list.

However, the court rejected the applicant's action on its grounds as follows:

The relevant incidence of the provisions of common law - tortious civil liability - has been analyzed, but a resolution of the case in question in this way is not possible as long as the legal regime of the litigation is governed by a special rule which, by virtue of the principle of law, "specialia generalibus derogant" is applied as a matter of priority and removes from application the common law, even in the absence of a legal provision for this purpose.

Furthermore, the principle of availability governing the civil process does not remove from application the rule of law invoked and cannot give another legal regime, indicated by the party, to settle the contentious relations than that determined by the special law.

The priority of the provisions of the special law also arises from the provisions of the insolvency law, namely Article 75 which establishes that from the date of the opening of the proceedings all judicial, extrajudicial or enforcement actions for the realization of claims on the debtor's estate shall be suspended by law, and the recovery of their rights may be made only in the context of insolvency proceedings by filing applications for admission of claims.

As such, this legal text is applicable to all claims and therefore from the date of the opening of the proceedings governed by the insolvency law can no longer be used the common law path for the tortious civil liability of the debtor.

It is true that there is also an exceptional situation covered by Article 75 paragraph 2 of the Law, that is to say that the law does not subject to the suspension of law, inter alia, the civil actions in criminal proceedings against the debtor, but such a legal provision is not incidental in the present case because the present action, even arising from a criminal trial, has been brought to the civil courts autonomously.

This follows from the fact that the agreement to admit the debtor's guilt for the offence of tax evasion was given in the criminal trial and as such, the civil action remained unsolved.

The fact that in the insolvency proceedings the patrimonial liability of the former shareholders or directors of the debtor company would had not been challenged or the amount due has not been recovered although registered in the definitive debts' list, there do not represent 
arguments for opening up the way of common law to solving litigation relations which are governed by special rules.

The procedure for the liability of former shareholders and directors of the debtor company, culpable of the insolvency status can take place only under the conditions referred to in Article 169 of the insolvency law. This is another possibility for creditors to be protected from the risk of insolvency of the debtor.

Thus, the amounts obtained in this way of liability of the directors guilty of insolvency will enter into the debtor's estate and will be intended, in case of reorganization of the payment of claims and in case of bankruptcy to cover the debts.

\section{Conclusions}

The insolvency proceedings are aimed at rescuing the debtor in financial difficulty and ultimately covering the debtor's claims that can no longer recover economically.

This procedure is a unique one and is a special procedure in relation to the common law procedure governed by the Code of Civil Procedure.

Whenever the two proceedings enter the competition, the insolvency procedure will always apply according to the "specialia generalibus derogant" rule.

The procedure of common law is not excluded in this situation either but it applies only in the exceptional cases provided for by law, namely when the civil side is to be settled in a criminal trial, it depends on the solution of the criminal trial and can be solved in the context of this process.

In the case of damage caused to a creditor by acts committed in connection with the activity of the insolvent company, its recovery can be made only by way of the procedure established by that law in order to fulfil its scope i.e. the payments of debts of the insolvent debtor towards its creditors (Nasz, 2007) and not by way of common law.

\section{References}

High Court of Cassation and Justice, $\mathrm{I}^{\text {st }}$ Section, decision no. 489 of 6 March 2019.

Adam, I., Savu, C. (2006). Legea procedurii insolvenţei, C.H. Beck Publishing House, Bucharest, 2006, p. 79.

Cărpenaru, S.D. (2012). Tratat de drept comercial, conform noului Cod civil, Universul Juridic Publishing House, Bucharest, 2012, p. 680.

Turcu, I. (2008). Tratat de insolvenţă, C.H Beck Publishing House, Bucharest, 2008, p. 297.

Pătulea, V. (2005). Sfera de aplicare a prevederilor Legii nr. 64/1995 privind procedura reorganizării judiciare a falimentului, Dreptul Journal, no. 2/2005, p. 29.

Nasz, C.B. (2007). Scopul şi obiectul procedurii insolvenţei, in $R D C$ no. 12/2007, p. 40 et sqq. 